AJSS, Vol. 7, No. 1, January - June 2008, pp. 29-45

ISSN 0975-329X| https://doi.org 10.12724/ajss.12.3

\title{
WOMEN EMPOWERMENT THROUGH MICROFINANCE: A STUDY OF SLUMS IN BANGALORE CITY
}

Vilas Mohan Kadrolkar', Gerard Rassendren²

$$
\text { Section - } 1
$$

\section{Introduction}

Gender discrimination continues to be an enormous problem within Indian society. Traditional patriarchal norms have relegated women to secondary status within the household and workplace. This drastically affects women's health, financial status, their education, and political involvement although women are an integral part of every economy. All round development and harmonious growth of a nation would be possible only when women are considered as equal partners in progress with men.

Empowerment is a multi-dimensional social process that helps people gain control over their own lives in their society, by acting on issues that they define as important.

1. Selection Grade Lecturer, Post Graduate Department of Management Studies, Siddaganga Institute of Technology, Tumkur - 03.E-mail: kmvilas@gmail.com.

2. Lecturer, PG Department of Economics, Christ College, Hosur Road, Dharmaram Post, Bangalore - 29. E- mail: gerard26feb@gmail.com 
Empowerment occurs within the sociological, psychological as well as economic spheres and also at various levels, such as individual, group and community. Empowering women puts the spotlight on education and employment, which are an essential element to sustainable development. The concept of empowerment is defined as the process by which women take control and ownership of their choices The core elements of empowerment have been defined as agency (the ability to define one's goals and act upon them), awareness of gendered power structures, self-esteem, and self-confidence (Kabeer, 2001).

Micro Finance for the poor and women has received extensive recognition as a strategy for poverty reduction and for economic empowerment. In this connection Micro-finance with Self Help Groups play an effective role for promoting women empowerment. In the early 1990s the National Bank for Agriculture and Rural Development1 (NABARD) started on a new nationwide micro finance initiative that links banks, NGOs and informal local self-help groups (SHGs). A review of the progress of programme under the aegis of NABARD indicates that by March 2001, the bank had trained 1,35,226 SHG members, 16,900 bank officers, provided awareness training to 4,158 NGO functionaries, trained 179 bank staff to be SHG promoters, exposed 4,500 government officials to micro finance and trained 205 NABARD officers. The Government of India had ushered in the new millennium by declaring the year 2001 as Women's Empowerment Year. A lot of programmes with fancy names: Swashakti and Stree Shakti for women's empowerment; through microcredit programmes has been announced.

In India, Micro finance scene is dominated by Self Help Group (SHGs)-Bank Linkage Programme as it is a cost effective mechanism for providing financial services to the "un-reached Poor". It has been successful not only in meeting financial needs of the rural and urban poor women but also strengthen collective self help capacities of the poor, leading to their empowerment. The focus is on getting the poor to mobilize their own funds, building their capacities and empowering them to leverage external credit.

SHG combines the goals of financial sustainability with that of creating community owned institutions. People in urban area needs more access to cash to cover the high cost of living than in rural areas. The micro finance project intervention in terms of formation and stabilization of SHGs contributes to extending credit support and promotion of thrift so as to promote viable economic activities. Against this background the present study has been carried on urban poor living in slum areas of Bangalore City and to find the role of SHGs in their economic and social life (especially for women), their savings as well as credit facilities. The objective of the paper is to assess the role of micro-finance - SHGs, as an alternative means for 
improving urban household's economic condition and the role of SHGs on women empowerment with special reference to childcare.

The paper is divided into four sections. The first section covers the rationale of the study, its scope, and objectives, which give clear idea about the whole study. The second section consists of a brief methodology adopted in the study, profile of the study area and the samples. Third section deals with SHGs (Micro finance) role in women empowerment, which covers awareness about the functioning of the SHGs, saving, loan from the SHGs and the Banks and defaulter status. Fourth section consists of the role of women in decision making with special reference to child education \& family's medical expenses as well as ways ahead for the improvement of SHGs functioning.

\section{Section - II}

\section{Methodology and Profile:}

The present study is based on the primary data collected through a structured questionnaire schedule from the $120 \mathrm{SHG}$ members in three slums of Bangalore city. Savings and income are taken as indicators for the impact assessment.

The study is based on stratified random sampling method. In first strata, the study covers three slums from Bangalore suburban on the basis of area, $\mathrm{SHGs}$ member and NGO linkage namely - Madivala, Rajendra Nagar and Vasantapura; second strata total of $18 \mathrm{SHG}$ s have been covered (6 each from three slums), on simple random sample basis and in the third strata $6-7$ members from each SHG have been selected randomly for the final field survey. The total sample size of the study is 120 .

\section{Profile of The Study Area:}

Bangalore is India's fifth-largest city, the momentum of its industrial and commercial growth unequalled in the country. It is a home for more than 250 high-tech companies, accounting for 35 percent of countries software export, called the 'Silicon Valley' of India and country's unofficial high-tech capital. Apart from this the city has many slums.

1. Madiwala Slum There are $600-700$ households with a population of 3200 members. One third of them are from middle-income group, the occupations are- casual workers in garments, vegetable vendors and auto drivers. 50-60 
percent of members are illiterate and is predominated by the Muslim community. The slum has very poor accessibility to the government facilities like sanitation and drinking water.

2. Rajendra Nagar Slum: There are 700 households with a population of 3450 members, and majority of them are daily workers in construction; few of them have petty business and auto rickshaw. The slum has good drinking, drainage and sanitation facility, also a school. The credit for the availability of these facilities goes to the NGO. Center for Social Action of Christ College that is working for the all-round development of this slum.

3. Vasanthapura Slum: In this slum there are 1000 households, with a population of 4150 peoples. The major occupation of the people is casual workers, labourers in garment industry and casual workers in factories. 70 percent of the population is illiterate and the slum has very poor basic amenities like- drinking water, roads, drainage system etc. As it is far away from the main city, the government has neglected this slum.

\section{Profile of Samples:}

The socio-economic profile of the respondents helps us to understand the background the people involved in the micro finance.

Family Profile: In the study area 60 per cent of the respondents are belonging to backward classes $(B C)$ remaining members are from Scheduled caste and scheduled tribe and 80 percent of them are from Hindu religion. The SHG composition is dominated by young and middle age up to 35 years with more than 67 percent (Table- 1 ). Most of them ( 88.3 per cent) are married and 10 percent are widow. The SHGs are providing safety net to married as well as widow women to overcome their family financial problems by empowering them. 
Table - 1. Family profile in the Study area

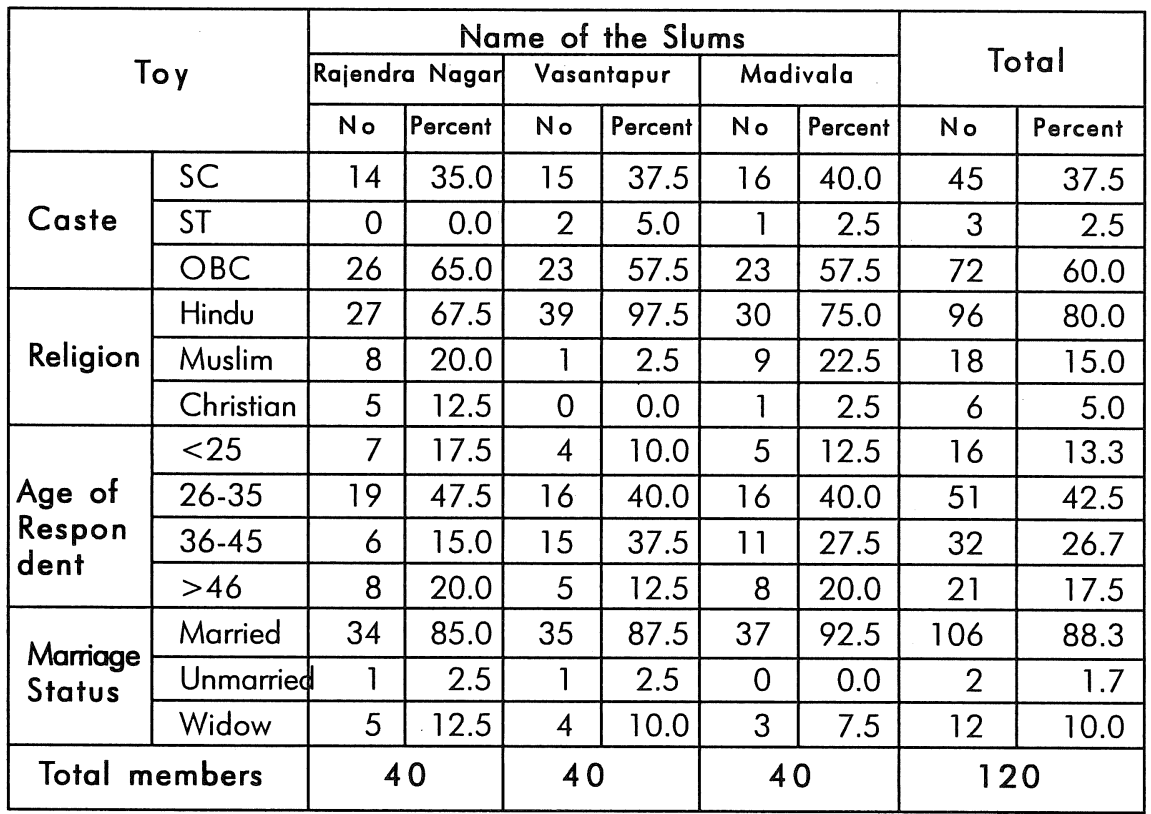

Source: Primary survey

Education: Education is a prime determinant of skill and quality of human resource. The educational status in the study area indicates that nearly 41 per cent of them are illiterate and majority of them are from Rajendra Nagar and Vasantapur. Surprisingly about 5 percent of the members are studied up to PUC and above. However, the education status is diverse among the groups, which is clear from figure -1 .

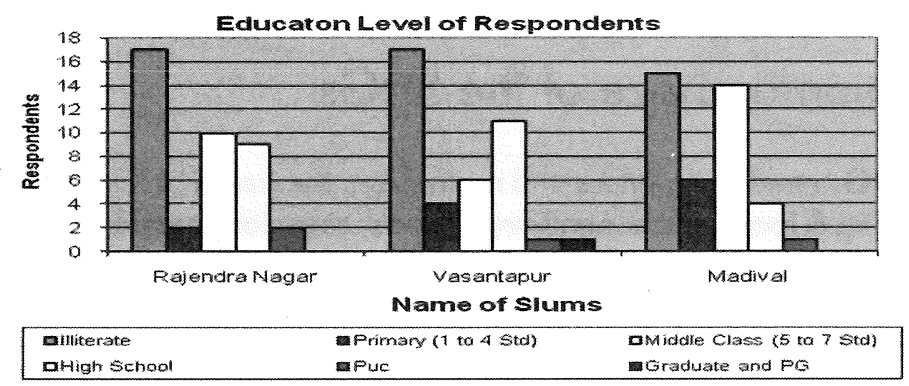

Figure - 1: Education levels of the samples 
Basic amenities: The study reveals that the slums have better accessibility to basic amenities. For instance about 64 per cent of them possess own house, 78 percent of them have access to electricity with own-metered connections and access to drinking water and toilet facilities shows the impressive result (Table-2).

Table - 2. Distribution of respondents by access to basic amenities (in per cent)

\begin{tabular}{|l|l|r|r|r|r|}
\hline \multicolumn{2}{|c|}{ Particulars } & \multicolumn{3}{c|}{ Name of Slums } & \multirow{2}{*}{ Total } \\
\cline { 3 - 6 } \multicolumn{2}{|c|}{} & $\begin{array}{c}\text { Rajendra } \\
\text { Nagar }\end{array}$ & Vasantapur & Madivala & \\
\hline $\begin{array}{l}\text { Housing } \\
\text { Facility }\end{array}$ & Own & 62.5 & 65.0 & 65.0 & 64.2 \\
\cline { 2 - 6 } & Rented & 37.5 & 35.0 & 35.0 & 35.8 \\
\hline \multirow{2}{*}{ Electricity } & Bhagya Joti & 27.5 & 12.5 & 25.0 & 21.6 \\
\cline { 2 - 6 } & Owned & 72.5 & 87.5 & 75.0 & 78.4 \\
\hline \multirow{3}{*}{\begin{tabular}{l} 
Electricity \\
\cline { 2 - 6 }
\end{tabular}} & Public stand posts & 77.5 & 82.5 & 62.5 & 74.2 \\
\cline { 2 - 6 } & Hand Pump & 2.5 & 2.5 & 0.0 & 1.7 \\
\cline { 2 - 6 } & Private tap & 20.0 & 15.0 & 37.5 & 24.2 \\
\hline Facility & Yes & 67.5 & 82.5 & 87.5 & 79.2 \\
\cline { 2 - 6 } & No & 32.5 & 17.5 & 12.5 & 20.8 \\
\hline \multicolumn{2}{|l|}{ Total mem } & 40 & 40 & 40 & 120 \\
\hline
\end{tabular}

Source: Primary survey

\section{Section - III}

\section{Micro Finance and Women Empowerment}

Micro Finance for the poor and women has received extensive recognition as a strategy for poverty reduction and for economic empowerment. Self-help groups and Micro financé are very closely linked; the former is used as a medium to generate and distribute financial capability so as to help deprived people to move up in the income ladder.

\section{Motivation and size of the SHGs}

Joining SHGs needs awareness and motivation; the size of SHGs has an impact on the saving \& loans of the members. Friends, especially neighbours', motivate 75 percent of the members. Self-motivation is only 17.5 percent, whereas NGO workers played a minor role in motivation. The average size of the group in the study is 15-20 members (Table-3). Almost 48 percent of the members have opined that the group size has been decreased; the reasons stated for the decline arenon-repayment of the loan, irregularity in attending the meeting and paying the 
amount of saving, shift in location of the members and in some cases marriage of the member.

Table - 3. Motivation for joining SHGs

\begin{tabular}{|r|l|r|r|r|r|}
\hline \multicolumn{2}{|c|}{ Particulars } & \multicolumn{3}{|c|}{ Name of Slums } & \multirow{2}{*}{ Total } \\
\cline { 3 - 6 } & $\begin{array}{c}\text { Rajendra } \\
\text { Nagar }\end{array}$ & Vasantapur & Madivala & \\
\hline \multirow{4}{*}{ Motivation } & Self & 15.0 & 20.0 & 17.5 & 17.5 \\
\cline { 2 - 6 } & Friend & 70.0 & 80.0 & 75.0 & 75.0 \\
\cline { 2 - 6 } & NGO workers & 15.0 & 0.0 & 7.5 & 7.5 \\
\cline { 2 - 6 } & Total & 100 & 100 & 100 & 100 \\
\hline \multirow{3}{*}{ Motivation } & Increased & 27.5 & 7.5 & 15.0 & 16.7 \\
\cline { 2 - 6 } & Stable & 22.5 & 72.5 & 15.0 & 36.7 \\
\cline { 2 - 6 } & Decreased & 50.0 & 20.0 & 70.0 & 46.7 \\
\cline { 2 - 6 } & Total & 100 & 100 & 100 & 100 \\
\hline
\end{tabular}

Source: Primary survey

\section{Occupational Structure}

Occupational structure determines the earning capacity of the members. In the study 50 per cent of the members are housewives, 45 per cent of them are daily wage earners, self employed (3.3), petty business (1.67) respectively. 67 percent of the members in Madiwala are daily wage earners, because they are engaged in construction work and garment industries for their livelihood. The occupational structure is diverse in nature and depending on the skills they acquired. Occupational structure does not reveal the real intensity of work culture or behaviour as this is highly correlated to day-to-day affairs.

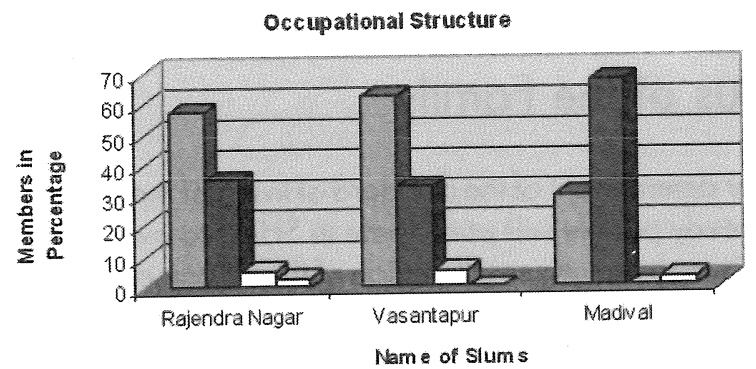

$\square$ House wife $\square$ Daily Workers $\square$ Self Employed $\square$ Petty Business

Figure - 2 Occupational Structures of the Members 


\section{Awareness about Working of SHGs}

When one joins the SHGs, it is the responsibility of members to get acquainted with working of SHG, which indicates high level of participation by the members. 62 percent of the members have the awareness about rules, regulation and cash in hand of the group (Table - 4). As far the bank balance is concerned only 57 percent of the members have the awareness, almost 80 percent of the members have the awareness about name of the bank in which the bank has the account and objective of the group. Around 65 percent of them have the awareness about saving of the group, members' loan taken and repaid. The overall observation about the awareness level among the members is satisfactory. The awareness level indicates the participation of the members in a group.

Table - 4. Distribution of members by awareness about group activities

\begin{tabular}{|l|r|r|r|r|}
\hline \multicolumn{1}{|c|}{ Group activities } & $\begin{array}{c}\text { Rajendra } \\
\text { Nagar }\end{array}$ & $\begin{array}{c}\text { Vasanta- } \\
\text { pur }\end{array}$ & Madivala & Total \\
\hline Rules and regulations & 67.5 & 72.5 & 47.5 & 62.5 \\
\hline Cash in hand & 62.5 & 77.5 & 47.5 & 62.5 \\
\hline Bank balance & 62.5 & 67.5 & 40.0 & 56.7 \\
\hline Savings of the group & 60.0 & 67.5 & 57.5 & 61.7 \\
\hline Number of members taken loan & 65.0 & 67.5 & 60.0 & 64.2 \\
\hline Number of members repaid loans & 65.0 & 75.0 & 55.0 & 65.0 \\
\hline $\begin{array}{l}\text { Name of the bank in which group } \\
\text { have the account }\end{array}$ & 80.0 & 75.0 & 82.5 & 79.2 \\
\hline Objective of the group & 85.0 & 77.5 & 80.0 & 80.8 \\
\hline Total No. of members & 40 & 40 & 40 & 120 \\
\hline
\end{tabular}

Source: Primary survey

\section{Income Status of the Family}

Income is the major determinant of the standard of living of the people. Generally, low-income and needy people will participate in SHGs to overcome their shortterm financial problems by saving small portion of their income. About 55 per cent of the respondents have income above Rs. 24,000. The proportion of high-income category respondents is more in Madivala (85.0) because the income level has a positive relation with the occupation. In Madiwala 68 percent of the members are daily workers with supplementary source of income, namely petty business. In Rajndra Nagar, 52.5 percent households have the income more than Rs. 24,000, and in Vasantapur, majority of the respondents are having income of less than Rs.24, 000 
per annum, because of 63 percent members are the housewives and availability of work is problem near to the area (Table - 5). Many women members independently involve in the economic activities and with other group members after joining SHGs. Therefore, they are now economically independent and contribute to the household income.

Table - 5. Distribution of households by income

\begin{tabular}{|l|c|c|c|c|}
\hline \multirow{2}{*}{$\begin{array}{c}\text { Income } \\
\text { Range }\end{array}$} & \multicolumn{3}{|c|}{ Name of the Slums } & \multirow{2}{*}{ Total } \\
\cline { 2 - 4 } & $\begin{array}{c}\text { Rajendra } \\
\text { Nagar }\end{array}$ & Vasantapur & Madivala & \\
\hline$<15000$ & $\begin{array}{c}12 \\
(30.00)\end{array}$ & $\begin{array}{c}21 \\
(52.50)\end{array}$ & $\begin{array}{c}4 \\
(10.00)\end{array}$ & $\begin{array}{c}37 \\
(30.83)\end{array}$ \\
\hline $15001-24000$ & 7 & 8 & 2 & 17 \\
& $(17.50)$ & $(20.00)$ & $(5.00)$ & $(14.17)$ \\
\hline $24001-50000$ & 20 & 9 & 22 & 51 \\
& $(50.00)$ & $(22.50)$ & $(55.00)$ & $(42.50)$ \\
\hline$>50000$ & 1 & 2 & 12 & 15 \\
& $(2.50)$ & $(5.00)$ & $(30.00)$ & $(12.50)$ \\
\hline Total & 40 & 40 & 40 & 120 \\
& $(100.00)$ & $(100.00)$ & $(100.00)$ & $(100.00)$ \\
\hline
\end{tabular}

Note: figures in the parenthesis indicate percentage to the total.

Source: Primary survey

Savings:

Self-Help Group (SHG) is a small voluntary association of poor people, with the purpose of solving their common problems through self-help and mutual help. The SHG promotes small savings among its members. Members of SHGs save equal amounts as decided in their groups. The meagre savings of an individual may not be sufficient to meet their needs, but all the savings of the groups members put together can be of great help to one or two members of the group. They act as the forum for the members to provide space and support to each other.

Majority of the members (42.5 percent) have saved the amount of Rs. 2501/5000 , followed with 26.7 percent in 5001-10000 category and around 26 percent of them have saved less than Rs. 2500. Only 5 percent of them have saved amount more than Rs. 10,000/- (Table - 6). Thus, the evidences are supporting that the saving has the positive relation with occupation and income of the member. 
Table - 6. Distribution of members by cumulative savings

\begin{tabular}{|l|c|c|c|c|}
\hline $\begin{array}{c}\text { Income } \\
\text { Range }\end{array}$ & $\begin{array}{c}\text { Rajendra } \\
\text { Nagar }\end{array}$ & Vasantapur & Madivala & Total \\
\hline 2500 & $\begin{array}{c}3 \\
(7.5)\end{array}$ & $\begin{array}{c}27 \\
(67.5)\end{array}$ & $\begin{array}{c}1 \\
(2.5)\end{array}$ & $\begin{array}{c}31 \\
(25.8)\end{array}$ \\
\hline $2501-5000$ & $\begin{array}{c}30 \\
(75.0)\end{array}$ & $\begin{array}{c}7 \\
(17.5)\end{array}$ & $\begin{array}{c}14 \\
(35.0)\end{array}$ & $\begin{array}{c}51 \\
(42.5)\end{array}$ \\
\hline $5001-10000$ & 7 & 6 & 25 & 38 \\
$(17.5)$ & $(15.0)$ & $(62.5)$ & $(31.7)$ \\
\hline Total & 40 & 40 & 40 & 120 \\
$(100.0)$ & $(100.0)$ & $(100.0)$ & $(100.0)$ \\
\hline
\end{tabular}

Source: Primary survey

\section{Purpose of savings in SHGs}

SHGs enhance the equality of status of women as participants, decision-makers and beneficiaries in the democratic, economic, social and cultural spheres of life. The SHGs provide savings mechanism, which suits the needs of the members. It also provides a cost effective delivery mechanism for small credit to its members. The major purposes of savings indicated by the members are health, education \& food security. This means when members face the problems and wish to solve them they want security to be provided to them and with respect to tiding over the issues they face. Marriage, celebration of festivals and construction of house are the other purposes cited by members.

Purpose of Savings

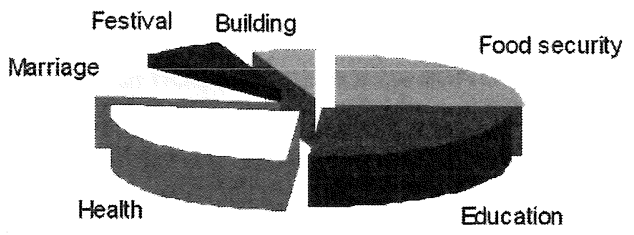

Figure - 3 Purposes of Savings 


\section{Sources of loan and its utilization}

Sanction of loans to SHGs by banks is based on the quantum of savings mobilized by the SHGs, but not for any specific purpose unlike in case of other schematic lending. The members borrow from SHGs and also from bank depending upon the need. The borrowings from SHGs are made on the basis of two-member witness giving the surety of repayment on behalf of members. The group fixes the rate of interest charged to the loan amount. From the bank the members can avail the individual loan on the recommendation of the group or group get loan sanctioned by bank under various scheme, which can be distributed among the members.

In case of SHGs loan almost 78 percent of the members borrowed the amount below Rs. 10,000; only 8 percent of them have borrowed more than Rs. 10,000 and 14 percent of them never borrowed from SHGs. This indicates that SHGs are able give short-term loan within Rs. 10,000/-to solve the day today problems faced by them. But in case of bank loan 37 percent of them have borrowed the loan from banks below Rs. 10,000/- and 37 percent of them have borrowed above Rs. 10,000/-(Table - 7). Comparatively the proportion of members who have borrowed above Rs. 10,000 from the banks is higher (37\%) than the proportion of members who have borrowed in the same range from the SHGs (7\%). This implies SHGs are able to generate micro credit, whereas banks help in providing higher credit amount to the members, which maybe use for education, construction of house \& starting a business.

Table - 7. Loan borrowed from bank and SHGs

\begin{tabular}{|c|c|c|c|c|c|c|c|c|}
\hline \multirow{2}{*}{$\begin{array}{l}\text { Loan amount } \\
(\text { Rs.) }\end{array}$} & \multicolumn{4}{|c|}{ Loan borrowed from SHG } & \multicolumn{4}{|c|}{ Loan borrowed from bank } \\
\hline & \begin{tabular}{|l|} 
Rajen- \\
dra \\
Nagar
\end{tabular} & $\begin{array}{l}\text { Vasan- } \\
\text { thapur }\end{array}$ & $\begin{array}{l}\text { Madi- } \\
\text { rala }\end{array}$ & Total & $\begin{array}{l}\text { Rajen- } \\
\text { dra } \\
\text { Nagar }\end{array}$ & $\begin{array}{l}\text { Vasan- } \\
\text { thapur }\end{array}$ & $\begin{array}{c}\text { Madi- } \\
\text { vala }\end{array}$ & Total \\
\hline No Loan & 25.0 & 12.5 & 5.0 & 14.2 & 17.5 & 37.5 & 20.0 & 25.0 \\
\hline$<2500$ & 12.5 & 25.0 & 12.5 & 16.7 & 0.0 & 15.0 & 0.0 & 5.0 \\
\hline $2501-5000$ & 15.0 & 32.5 & 47.5 & 31.7 & 10.0 & 10.0 & 7.5 & 9.2 \\
\hline $5001-10000$ & 35.0 & 22.5 & 30.0 & 29.2 & 20.0 & 10.0 & 40.0 & 23.3 \\
\hline $10001-15000$ & 7.5 & 2.5 & 2.5 & 4.2 & 20.0 & 0.0 & 17.5 & 12.5 \\
\hline $15001-25000$ & 2.5 & 0.0 & 2.5 & 1.7 & 20.0 & 22.5 & 5.0 & 15.8 \\
\hline$>25000$ & 2.5 & 5.0 & 0.0 & 2.5 & 12.5 & 5.0 & 10.0 & 9.2 \\
\hline Total & 100.0 & 100.0 & 100.0 & 00.0 & 100.0 & 100.0 & $100 . c$ & 100.0 \\
\hline
\end{tabular}

Source: Primary survey 


\section{Purpose of loan:}

Loan may be granted by the SHG for various purposes to its members. The bank does not decide the purpose for which the SHG gives loans to its members. The group will discuss and decide about the purpose for which loans are to be given to its individual members by the SHG. 68.6 percent of them borrowed loan for consumption purpose, 37 percent of them for education of the children, 27 percent of them for health, and 19.5 percent fro marriage purpose (Figure -2). Only 5 percent of them have borrowed for income generating activities like 2 petty shops, 2 -cycle shop, 1 for flower business and 1 for the purchase of auto. This clearly indicates that the amount borrowed is only to solve their problems of day today life than productive purposes.

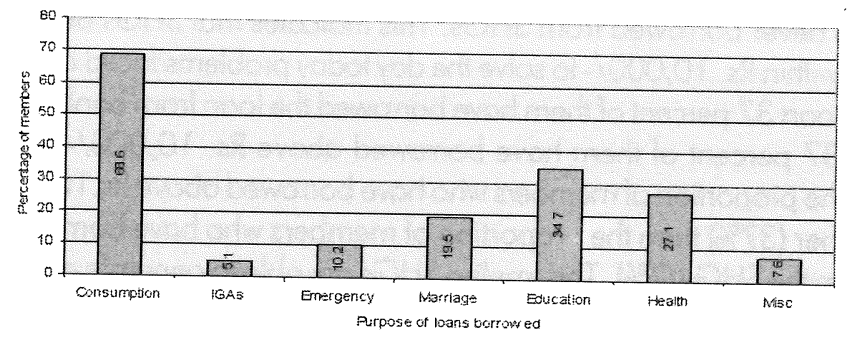

Figure - 4: Purposes of loans

\section{Repayment of Loan:}

Only one member of a group gets a loan at a time, the preference to whom loan should be given is decided by the members themselves depending on the urgency of the need. The members availing loans have to pay interest of 2 percent per month. Failure to pay loan instalments, interest charges and savings on the day of meeting invites a fine of Re. 1.00 per month. If any member defaults the payment, the other members of the group are also denied further loans. This has activated the group to bring collective pressure on the defaulter.

Out of total samples 86 percent of them have borrowed the money from the SHGs and 75 percent of them have borrowed from the banks. The amount borrowed from the banks is higher as compared to the SHGs i.e. average amount borrowed from SHGs is Rs. 9500/- and from bank it is Rs. 14, 800/- The average percentage of repayment under SHGs is 17.23 percent, where as it is 34.45 percent in case of banks. Thus repayment under bank is good as compared to the SHGs. This is because of pressure of banks for the repayment is more as compared to the SHGs. (Table-8) 
Out of the total borrowers from the SHGs only 53 percent of them have paid the amount regularly, whereas almost 47 percent of them are defaulters. In comparison to this, in case of banks 66 percent of them have paid the amount regularly and 34 percent of them are the defaulters. This shows that recovery of the loan from the $\mathrm{SHGs}$ is poor as compared to the banks.

Table - 8. Details about total loan, repayment and default rate (Amount in Rs.)

\begin{tabular}{|c|c|c|c|c|c|}
\hline $\begin{array}{l}\text { Source } \\
\text { of } \\
\text { loan }\end{array}$ & $\begin{array}{c}\text { Particu- } \\
\text { lars }\end{array}$ & $\begin{array}{c}\text { Rajendra } \\
\text { Nagar }\end{array}$ & $\begin{array}{c}\text { Vasant- } \\
\text { hapur }\end{array}$ & Madivala & Total \\
\hline \multirow{3}{*}{ SHGs } & Loan & $246000(29.1)$ & $286500(34.0)$ & $221000(36.9)$ & $978500[85.8]$ \\
\hline & Repayment & $48000 \quad(21.8)$ & $47100(38.2)$ & $73500(40.0)$ & $168600(53.4)$ \\
\hline & Defaulters & $198000 \quad(37.5)$ & $239400(29.2)$ & $147500(33.3)$ & $809900(46.6)$ \\
\hline \multirow{3}{*}{ Bank } & Loan & $549000 \quad(36.7)$ & $329500(27.8)$ & $453500(35.6)$ & $1332000[75.0]$ \\
\hline & Repayment & $107400(22.0)$ & $175100(37.3)$ & $176500(40.7)$ & $459000(65.6)$ \\
\hline & Defaulters & $441600(64.5)$ & $154400(9.7)$ & $277000(25.8)$ & $873000(34.4)$ \\
\hline
\end{tabular}

Note: Figures in parenthesis indicate percentage to total number of borrowers

Figures in [] indicates percentage to total number of members

Source: Primary survey

\section{Section - IV}

\section{Women Empowerment with Reference to Child Care}

Women empowerment has gained momentum in the recent past. The SHGs have given women a forum where in they come together, save some money which helps them to solve their day to day problems and also get training exposure. Women's role with regard to the children's education has shown remarkable improvement. Around 43 percent of the members say's, the members themselves take decision regarding the children's education. Husband's role in decision-making is 30 percent and other family members are contributing for 27 percent. Slum-wise comparison indicates that, in Rajendra Nagar 65 percent and 42 percent in Madiwal have taken the decision with regard to child's education. (Table-9) This improvement has relation with the education of the members, as there is more illiteracy in these two slums forced them to send their children to school.

In case of medical expenses of the family major role is played by the husband (71 percent) as it has financial implication. It indicates that, in male dominated society women are still struggling to get financial power. 
Table - 9. Decision regarding child education and medical expenses in the family

\begin{tabular}{|c|c|c|c|c|c|c|c|c|}
\hline \multirow{2}{*}{$\begin{array}{c}\text { Loan amount } \\
\text { (Rs.) }\end{array}$} & \multicolumn{2}{|c|}{ Rajendra Nagar } & \multicolumn{2}{|c|}{ Vasantapur } & \multicolumn{2}{|c|}{ Madival } & \multicolumn{2}{|c|}{ Total } \\
\hline & \begin{tabular}{|l|} 
Child \\
Educ- \\
ation
\end{tabular} & $\begin{array}{l}\text { Medical } \\
\text { Expen- } \\
\text { ses }\end{array}$ & $\begin{array}{l}\text { Child } \\
\text { Educ- } \\
\text { ation }\end{array}$ & \begin{tabular}{|c|} 
Medical \\
Expen- \\
ses
\end{tabular} & $\begin{array}{l}\text { Child } \\
\text { Educ- } \\
\text { ation }\end{array}$ & \begin{tabular}{|c|} 
Medical \\
Expen- \\
ses
\end{tabular} & $\begin{array}{l}\text { Child } \\
\text { Educ- } \\
\text { ation }\end{array}$ & \begin{tabular}{|} 
Medical \\
Expen- \\
ses
\end{tabular} \\
\hline Yourself & 65.0 & 30.0 & 20.0 & 2.5 & 42.5 & 22.5 & 42.5 & 18.3 \\
\hline Family member & 10.0 & 10.0 & 32.5 & 10.0 & 40.0 & 10.0 & 27.5 & 10.0 \\
\hline Husband & 25.0 & 60.0 & 47.5 & 87.5 & 17.5 & 67.5 & 30.0 & 71.7 \\
\hline Total & \multicolumn{2}{|c|}{$100(40)$} & \multicolumn{2}{|c|}{$100(40)$} & \multicolumn{2}{|c|}{$100(40)$} & \multicolumn{2}{|c|}{$100(120)$} \\
\hline
\end{tabular}

Note: Figures in bracket indicates total number of members

Source: Primary survey

\section{Comparison of the Status}

The SHGs membership has improved women's status, as it gives exposure, helps to generate saving and provides opportunities of acquiring training which helps women to improve upon their status in the society. Comparing the situation of women before and after becoming a member of SHG's, the primary data of the study shows that 72 percent of the members felt that their socio-economic status has improved (Table-10). This clearly indicates that the SHGs membership has improved the status of women and helped for empowerment. 69 percent of the members have indicated that they got good recognition in the community because of the SHGs membership. Thus, from the analysis it can be concluded that, being a member of the SHGs has helped women to improve upon the socioeconomic status, recognition in community, which is a clear indication of empowerment of women. 
Table -10. Comparison of the status, recognition in the community

\begin{tabular}{|c|c|c|c|c|c|c|c|c|}
\hline \multirow{3}{*}{ Particulars } & \multicolumn{6}{|c|}{ Name of Slum } & \multirow{2}{*}{\multicolumn{2}{|c|}{ Total }} \\
\hline & \multicolumn{2}{|c|}{ Rajendra Nagar } & \multicolumn{2}{|c|}{ Vasantapur } & \multicolumn{2}{|c|}{ Madival } & & \\
\hline & Nos. & Percent & Nos. & Percent & Nos. & Percent & Nos. & Percent \\
\hline \multicolumn{5}{|c|}{ Comparison of socio economic status } & & & & \\
\hline Average & 2 & 5.0 & 6 & 15.0 & 5 & 12.5 & 13 & 10.8 \\
\hline Good & 4 & 10.0 & 6 & 15.0 & 10 & 25.0 & 20 & 16.7 \\
\hline Very good & 34 & 85.0 & 28 & 70.0 & 25 & 62.5 & 87 & 72.5 \\
\hline Total & 40 & 100 & 40 & 100 & 40 & 100 & 120 & 100 \\
\hline \multicolumn{4}{|c|}{ Recognition in the community } & & & & & \\
\hline Average & 2 & 5.0 & 5 & 12.5 & 12 & 30.0 & 19 & 15.8 \\
\hline Good & 1.1 & 27.5 & 4 & 10.0 & 3 & 7.5 & 18 & 15.0 \\
\hline Very good & 27 & 67.5 & 31 & 77.5 & 25 & 62.5 & 83 & 69.2 \\
\hline Total & 40 & 100 & 40 & 100 & 40 & 100 & 120 & 100 \\
\hline
\end{tabular}

Source: Primary survey

\section{Conclusion:}

The education status is diverse among the groups and areas have better accessibility to basic amenities. Occupational structure shows that majority of them are housewife and daily workers. The SHGs are providing safety net to married as well as widow women to overcome their family financial problems by empowering them.

Majority of the members have been motivated to join SHGs by friends. Members have a fair idea about the working of the SHGs and they are also participating in the process. Members have got training in activities like cookery, which has helped them in skill development. The SHGs have made the positive impact on the child care and education, the members found that their socio-economic status has gone up and recognition in the community has also improved. There is high level of cooperation among the SHG members. Thus, SHGs has created a positive impact on urban poor women and helped them in getting recognition in community. This proves our hypothesis "Self- Help Groups has made a positive impact on women empowerment". 


\section{Ways Forward}

Micro-enterprise development of the poor under SHG framework underlines the need for a deliberate policy frame in favour of assurance in terms of technology backup, product market and human resource development. However, in the context of economic liberalization, there are indications that the markets are turning out to be unfriendly to the poor. Hence, there is a need for the development of an innovative and diversified micro-finance sector, which will make a real contribution to women empowerment. This requires a focused approach by the government for the maximum upliftment of women.

\section{References:}

1. Berger, Margure (1989) -Giving Women Credit-The Strength and Limitations of Credit as a tool for Alleviation of poverty, World Development, Vol-17, No.7, Pp.1017-1032.

2. Chiranjeevulu T. (2003), "Empowering Women Through Self Help Groups - Experiences in Experiment", Kurukshetra, March.

3. Dodkey, M.D. (1999), "SHGs and Micro Credit, Sustaining Rural Women", Social Welfare, March, 45. 12: 19-20

4. Harper, Malcolm, Berkhof, Andrews, and Ramakrishna R V ( 2005) - SHG-Bank Linkage: A Tool for Reforms in Cooperatives, Economic and Political Weekly, April, 23.

5. March Sackrey, Charles, The Political Economy of Urban Poverty, W. W. Norton and Company. Inc., New York, Introduction, P.1.

6. Mordurch, Jonathan and Stuart Rutherford (2003) -"Micro finance Analytical Issues, Challenges and Policy Option", in Priya Basu (Ed)-'India's Financial Sector: Issues, Challenges and Policy Options', Oxford University Press.

7. Naranaswamy N.S. Manivel and B. Bhaskar (2003), "Networking SHGs and Cooperatives An Analysis of strengths and Weaknesses", Journal of Rural Development. Vol.22 P.3.

8. Planning Commission- (2005) - Micro finance and Empowerment of SC Women: An Impact Study in UP and Uttaranchal, BL Centre for Development Research and Action Lucknow.

9. Rajasekhar D, (2004) Micro-Finance, Poverty Alleviation and Empowerment of Women: A study of Two NGOs from Andhra Pradesh and Karnataka, (ISEC Monographs: 4), Institute for Social and Economic Change, Bangalore.

10. Ramanjaneyulu, R (2006) - 'Economic Empowerment of Women in India', Anmol Publication, New Delhi. Pp. 1-28

11. Seibel, Hans Dieter and Harish Kumar R. Dave (Nov, 2002) - "Commercial Aspects of SelfHelp Group Banking in India: A Study of Bank Transaction Costs". Micro credit Innovation Department, NABARD, Mumbai. Pp.1-23. 
12. Sen, Amartya, (2006)- Poverty and Famines, Oxford University Press, chap-2, P.9.

13. Sinha, Frances and The Impact Assessment Team (July, 2003) -" Impact Assessment of Micro finance-Interim Findings from a National Study of MFI's in India", EDA Rural System Pvt. Lmt. Gurgaon and SIDBI, Luknow.

14. Srivastava, Pradeep (2005) -"Micro finance in India: Odysseusor Interlopers? "Economic and Political Weekly, August, 13, Pp. 3626-3628.

15. Thorat, Y.S.P and Graham A.N.Wright (2005) -"Microfinance: Banking For the Poor, not Poor Banking", Business Line, Financial Daily from Hindu Group of Publications, Tuesday March 15.

16. Williams, Colin, C. and John Windebank (2001) -"Urban Development-Revitalizing Deprived Urban Neighbourhoods: Assisted Self-Help Approach", Ash gate Publishing Limited, Aldershot, U.K. Pp.1-34. 